\title{
Value of Literature in Language Teaching
}

\author{
Srinivasa Rao Idapalapati \\ English Language Unit, University of Tabuk \\ Tabuk - 71491, Saudi Arabia \\ Tel:966-537-135-547_Ｅ-mail: idasrini@gmail.com
}

Received: January 9, 2012

Accepted: January 16, 2012

Published: March 15, 2012

doi:10.5430/wjel.v2n1p64

URL: http://dx.doi.org/10.5430/wjel.v2n1p64

\begin{abstract}
In view of the conflicting views about the traditional literature based vs. authentic materials in teaching English as a second and foreign language as well as English for academic and specific purposes, a brief survey about the benefits of the materials reveals that the literature based materials can capture the attention of the learners by connecting the content to the real time situations more impressively and artistically than authentic materials and can make the learning more meaningful. The information required has been collected in the form of questionnaires and oral interviews and an analysis of the data has been presented in the narrative form in combination with the accounts of analyses of the review of similar literature.
\end{abstract}

Keywords: Language and literature, Engaging texts, Real life connections, Academic and specific purposes

\section{Backdrop}

The purposes of learning English as a language of the world are multifarious. A vast majority of the people in the world learn English as a second language or foreign language and for literacy and educational purposes. However, the primary purpose of learning a second language or a foreign language is associated, mostly, with the successes in the businesses outside. The National Council of Teachers of English (1990) states that the "development of literacy, the use of language to construct personal and public worlds and to achieve full participation in society, through the learning and teaching of English and the related arts and sciences of language" as their mission. The Ministry Of Education of Singapore (2008) found that the "proficiency in English will give pupils access to the business world, the service and entertainment industries, and opportunities for further training and education" (p.6). The Curriculum Council report of Japan (1998) holds that the purpose of curriculum is to encourage the children to cultivate "well balanced rich humanity and sociality." Johnston (2002) was shrewd in stating that "English language teaching (ELT) is not merely a matter of training students in a particular set of skills. Rather, the occupation of ELT is profoundly imbued with values" (p.1). The values are further complex and conflicting as they are dependent on cultures and societal norms. Unless a student is suitably trained to be fit for the global context with the knowledge of the normative values, the communication proves to be detrimental. Such training demands the selection of the materials for the courses and the lessons suitable for the formation of international communication basal.

\section{A Recount of Reflections}

English literature in different forms is being used for teaching English language. Martindale (2008) finds that film has become a conventional pedagogy for teaching Shakespeare. Fiorito \& Heather (2009) stated that "Regularly incorporating foreign films into our academic reading classes has given us all a break from the routine reading of textbooks and articles while effectively developing students" reading skills at all levels. Sue \& Kelli (2009) hold that drama and movement can create a stimulating physical environment congenial for retaining information required for all the literacy skills of a language. Monnin (2010) argues in length about the importance of using graphic novels in teaching English for multi-modal literacy facets. Brodsky (n.d.) chooses the graphic novel as an elective teaching topic as it offers "multilevel reading experiences" suitable for all learners. The text and image level readings of a graphic novel improve the basic reading as well as analytical skills of learners. Finch (2003) identifies that poetry "without the constraints of grammatical accuracy" can be considered an ideal tool for the acquisition, personal expression and creativity of English language. Benegas (2010) uses literature in his English language classes because he is a reader and loves sharing the pleasure and enthusiasm in reading fiction and he finds that literature enables the individuals grow personally and socially developing their cultural awareness. In view of Gray (2005) the translated versions of native literature of a non-English speaking country into English could be better sources for an L2 student. Peggy, Sharolyn \& Sharon (2004) suggests story book reading for instruction in vocabulary and comprehension. The story books provide 
the opportunities that enable the teachers relate the words to familiar concepts. Collie \& Slater (1987)stated

"literature provides a rich context ... with the basic skills of language learning (p.5).

\section{Literature as a Source of Engaging Teaching Materials}

The bedtime stories by grannies, the narrations of adventures by old timers and warhorses, and the short tales of the wise men play universally a great deal in the formative years of children in spite of the cultural and linguistic variations. An EFL/ESL teacher dealing with adults can consider such stories and tales in the formative stage of the language. Short stories relevant to particular age group proves to be more engaging than an article on an issue, as the story provides a familiar context for discussions and understanding. A class proves to be productive when it is engaging, affectionate and enjoyable. Among a sea of articles on how to train a trainer, the story of Lessons from a Pony by Steffins (n.d.) stands unique in its affect on the novice trainers. One can understand the impact of the story on the readers just by reading a few lines in the last part of the story. .

I told both of them how long and carefully I had taught my horse..."I taught my mare that trick," I said, "I have taught her all she knows and I never hit her, not once." (p.2)

By relating the content of the lesson to the personal lives and the future needs of the learners, teachers can have their learners' active participation in the learning program and can further their motivational levels. Literature can dispense a greater scope for multi-faceted "instructional conversations" or "substantive conversations" that value learners" contributions in the interactions between and among the teacher and learners for co-construction and interpretation of understandings. (Nystrand,1997, p.7)

Besides the classic literature, the current fiction also proves to be gripping and informative for strengthening one's 'linguistic competence'. Kocis (2002) holds that the curriculums should reflect the modern culture as a whole that encompasses the individual cultures of learners as well. The canon of literature for academics should be considered for renovation and include the current fiction relevant to the different cultures of the learners. When The Alchemist of Paulo Coelho was introduced into the curriculum of a university in an Arabic country, the students found it very interesting to learn about the journey of a boy to Egyptian pyramids and so they were more eager to involve in the activities designed by the teacher. John Grisham's fiction gives a good understanding about the events that go around in the US law firms and courts. The popular fiction by author like Sidney Sheldon and Jaffrey Archer, besides providing the native cultural backdrop, can supply good stuff about the local slang and style of the dialect.

Levi (1984) interwove his experiences in chemical laboratories, at Auschwitz concentration camps of Germany and his perceptions life in his fiction and especially The Periodic Table offers a good content of English for science students. A teacher dealing with an ESL or EFL class for the students of chemistry as an undergraduate major The Periodic Table works magically in understanding the different aspects of grammar and structures of language as the book offers a familiar background with the simplistic style of the language use. The students also understand the creativity in presenting the role of 'chemistry' in the makeup of the earth, world and the lives of the people apart from the facts about the elements in the periodic table. Even the non-chemistry background students find it useful and interesting as they would learn many facts about chemistry and its operations in their lives, not in the form of a textual exposition. The following extract exemplifies the punch of literary creativity and the language use by Levi.

There are the so-called inert gases in the air we breathe... they do not interfere in any chemical Reaction, do not combine with any other element... The little that I know about my ancestors presents many similarities to these gases. ( p.4)

Franknoi (2009) expounds that the abstract ideas and the concepts of 'physics' can be brought forward in the concrete form, to the novice, struggling students through the fiction by authoritative writers with advanced degrees in Science. The teachers dealing with the students in management courses can turn to the fiction by authors like Patrick Lencioni, John Guaspari and John Perkins. Lencioni provides a spicy delineation of the three fears that the triumphant business tycoons conquer on their way towards success in his Getting Naked (2010). Hardly any expositional text can deliver the 'three fears' that most successful business people have to overcome as effectively as Lencioni has delivered in his fiction. Guaspari (2000) provides the philosophy of the 'value effect' in the whodunit genre that never disappoints the young readers, through The Value Effect: A Murder Mystery about the Compulsive Pursuit of "The Next Big Thing". The intriguing international commerce and the resultant events of the world like the 'Gulf War', 'Saddam Hussein', Bin Laden and the American Invasions into different parts of the world can best be understood from the kindred fiction works like The Confessions of an Economic Hit Man, by John Perkins (2004). Businesses thrive on the social skills of their executives and according to Carledge \& Kiarie (2001) "literature is a tool for imparting social skills" because literature can provide the teachers with the scope of 'direct instruction' to the essential social skills. 
Donna (1998) found that in contrast to the complex mathematical and analytical tools used by the current economists, the greatest tools adapted by Adam Smith for documenting his observations and theories of political economy were prose and rhetoric. Donna's anecdote tells us the way he used literature for teaching economic concepts.

Typically, only one or two students in the class know that Shylock was the famed moneylender in Shakespeare's The Merchant of Venice. Adding a quick plot synopsis to my lecture did not seem to help students make a connection between past and present money lending practices, both legal and illegal. Finally, I added The Merchant of Venice by William Shakespeare to my syllabus. (p.330)

Estes \& Vasquez (2001) bring us a story that demonstrates the potential of literature in contrast to the expositional texts.

One teacher decided to experiment with books in her social studies class. In one section of her U.S. history class, she taught the unit on the American Revolution using only the textbook as reading for the students. In another class, she used only Johnny Tremain, a novel by Esther Forbes about the American Revolution, for the reading. And with a third group of students, she used both the textbook and the novel. At the end of the unit, all students took the same test the teacher had given in years past. It comes as no surprise to learn that the students who had the benefit of both books, the novel and the textbook, scored highest by one letter grade over the next highest group. But who scored second? The students who had only the novel and not the textbook for their reading. Why? Our guess is that the novel put the events of the Revolution in human, value-laden terms. (p. 507)

In my enquiry, I too encountered a similar comment when a student said,

When my social studies teacher was talking about the French Revolution we were very uninterested to what she was talking. For many days I was in total confusion about the French Revolution and its consequences and the movements in that period. All this confusion was cleared when I attended the classes of English on "The Tale of Two Cities.

The horrors of the Nazism, the parables of survival and the holocaust in Germany were best understood through the novels of Elie Wiesel. A student who always felt that history and knowing about other cultures and what happened in other countries was a big boredom, after attending the classes on Elie Wiesel's Night started saying that it's very important to study history and learn about the events in history that happened all over the world. He commented that "our English classes are providing greater insights into the world events and learning English in this way is really interesting and encouraging". Many of my students were of the view that the evolution of the earth and the related principles of physics could be better understood through Stephen W. Hawking's A Brief History of Time. Though it's not a complete fiction, we included it in our English syllabus for our Physics major students and after the completion of the book, the feedback from a majority of the students was that they were doing two things at one go. "We must thank our English teachers for introducing such wonderful books that let us learn English, simultaneously reinforcing our understanding about the concepts of astronomy and physics". Rachel Carson's The Silent Spring (1962) gives a grisly vision of the consequences of deforestation and the escalating poisonous emissions into the otherwise pleasant and balanced environment. Our choice of teaching English to the students of Environmental Science major through The Silent Spring drew the comments like

We understood the importance of responding to the environmental issues more from our English classes. Our regular science classes give us the theoretical base and the scientific facts, but our English classes, apart from giving us the language principles and vocabulary required for our academic purposes, are providing us the comprehensive outlook on 'how to respond' and 'why to respond' to our theoretical knowledge.

\section{Conclusion}

In spite of the emergence of several innovative teaching strategies, the literature based instruction stands unique in many ways in the making of the citizens of the world. As it was stated by Greenslate (2006)

Literature, poetry, essays, letters, and speeches are means by which humans communicate with each other about life-changing experiences and they help us to see the world anew... Every poem or work of literature can be connected to present day social justice issues. Our job as educators is to find these connections, let students explore them, answer questions, and provide support. If you do this, you will be amazed as you watch your students leap to new levels of engagement and meaningful learning. (p.28) 
There is an immense need for scholarly works on the literature based communication skills, language skills, and soft skills development activities and training programs, especially for the students in the undergraduate studies. As literature can be called the treasure of human achievements and the personality traits in the finest form and so the literati can view it as a desirable source for teaching language and for developing "communicative competence" (Hymes, 1972) by continual improvisation to the ever changing needs and perceptions of younger generations.

\section{References}

Brodsky, L. (n.d). Teaching Something New. http://www.graphicnovelreporter.com/content/teaching-something-new-op-ed

Benegas, D. (2010). The Role of Literature in ELT. http://www.teachingenglish.org.uk/blogs/dario-banegas/role-literature-elt-part-one

Carledge, G. \& Kiarie, M.W. (2001). Learning Social Skills. Teaching Exceptional Children,34-2, December, P.40+.

Carson, R. (1962). Silent Spring. Boston: Houghton Mifflin.

Coelho, P. (2006). The Alchemist. San Francisco: Harper.

Collie, J. \& Slater, S. (1987). Literature in the Language Classroom: A Resource Book of Ideas and Activities. Cambridge: Cambridge University press.

Donna, M. K.G. (1998). Using the Merchant of Venice in Teaching Monetary Economics. Journal of Economic Education. Volume: 29/4: 330

Estes,T. H. \& Vasquez. L. D (2001). Literature as a Source of Information and Values. PhiDelta Kappan. 82/7: 507.

Finch, A. (2003). Using poems to teach English. English Language Teaching, 15(2), 29 - 45.

Fiorito, M. \& Heather,T. (2009). Using Subtitled Foreign Films In The Language Class Room. Essential Teacher, (6/2). http://www.tesol.org/s_tesol/secet.asp?CID=2007\&DID=12418

Fraknoi, A. (2009). Science Fiction Stories with Good Astronomy \& Physics: A Topical Index. Astronomical Society of the Pacific, Version 5.1; August 2009. http://www.astrosociety.org/education/resources/scifi.html\#topic

Fraknoi, A. (2003). Teaching Astronomy with Science Fiction: A Resource Guide. The Astronomy Education Review, Issue 2, Volume 1:112-119. doi:10.3847/AER2002009.

Gray, R. (2005). Using Translated First Language Literature in the Second Language Classroom. The Internet TESL Journal, Vol. XI, No. 12, December.

Greenslate, C. (2006). Social Justice and Language Arts. Green Teache, 80: $28+$.

Guaspari, J. (2000). The Value Effect. San Francisco: Berrett-Koehler.

Hardy, T. (1886). The Mayor of Casterbridge. New York: Oxford.

Hawkings, S.W. (1988). A Brief History of Time. New York: Bentam Dell Publishing House. http://www.fisica.net/relatividade/stephen_hawking_a_brief_history_of_time.pdf

Hymes, D. H. (1972). On communicative competence. In J. B. Pride \& J. Holmes (Eds.), Sociolinguistics, pp. 282-293. Harmonsworth UK: Penguin Books.

Johnston, B. (2002). Values in English Language Teaching. NJ: Lawrence Erlbaum Associates, Mahwah.

Kocis, J. (2002). A "new American" Literature. Multicultural Education, 9(4), p.33+.

Lencioni, P. (2010). Getting Naked. San Francisco: Jossey-Bass.

Levi, P. (1984). The Periodic Table. Translated from the Italian By Raymond Rosenthal. New York: Schocken Books.

Martindale, S. (2008). Shakespeare on Film: Viewing Shakespeare inside the Classroom and Out. English Drama Media. 10/2 P.19.

Ministry of Education, Singapore (2008). English Language Syllabus 2010 Primary (Foundation) \& Secondary (Normal [Technical]). Singapore: Govt.

Monnin, K. (2010). Teaching Graphic Novels: Practical Strategies for the Secondary ELA Classroom. Gainsville: Maupin House Publishing. 
Nystrand, M. (1997). Opening dialogue: Understanding the dynamics of language and learning in the English classroom. New York: Teachers College Press.

Peggy, H., Sharolyn P.D. \& Sharon, V. (2004). Storybook Reading: Improving Vocabulary and Comprehension for English-Language Learners Teachers Can Use This Strategy to Systematically Build the Vocabulary and Comprehension Skills of Primary-Grade English-Language Learners through Daily Read-Alouds. The Reading Teacher, 57/8, P. 720+.

Perkins J. (2004). Confessions of an Economim Hit Man. San Francisco: Bettet-Koehler

Steffins, L. (n.d.). Lessons from a Pony. URL http://www.efl.net/caol.htm

Sue A. R, Kelli R. P (2009). Using Drama and Movement to Enhance English Language Learners' Literacy Development. Journal of Instructional Psychology, 36/2: 148+.

The National Council of Teachers of English (1990). Mission.USA. http://www.ncte.org/mission

The Curriculum Council, Japan (1998). National Curriculum Standards Reform for Kindergarten, Elementary School, Lower and Upper Secondary School and Schools for the Visually Disabled, the Hearing Impaired and the Otherwise Disabled. Japan. http://www.mext.go.jp/english/news/1998/07/.htm980712. 